\title{
A Calculation Method of Equivalent Circuit Constants with Mutual Leakage Reactance on Synchronous Machine with Damper Winding
}

\author{
Takashi Kano Member (Nagoya University) \\ Hiroki Nakayama Member (Polytechnic University) \\ Takahiro Ara Senior Member (Polytechnic University) \\ Toshiro Matsumura Member (Nagoya University)
}

Keywords: synchronous machine, field current, mutual leakage reactance, d-axis transient reactance, DC decay testing method, equivalent circuit

The mutual leakage reactance between the d-axis damper and field windings is ignored in the conventional $\mathrm{d}$-axis equivalent circuit. It has been pointed out that the calculated value of the field transient current differs considerably from the measured value when this reactance is not taken into account. A method to determine this reactance has been reported previously, but this method has problems concerning the measurement precision. The authors have previously presented a calculation method of equivalent circuits, adapting a standstill test with a small-capacity DC power supply (DC decay testing method), using two synchronous machines of the same specifications (one with damper winding, the other without). Yet, this method is not practical because of the use of two machines.

This paper presents a calculation method of equivalent circuit constants taking into account the mutual leakage reactance to accurately represent the field transient current using a single machine.

Figure 1 shows an equivalently-transformed d-axis equivalent circuit considering the mutual leakage reactance $x_{23}$. The proposed method involves three steps. First the DC decay testing method, previously reported by the authors, is carried out to obtain three d-axis operational impedances $\left(X_{d o}(j s)\right.$ : when the field winding is opened; $X_{d s}(j s)$ : when the field winding is shorted; and $X_{d k}(j s)$ : when the field winding is shorted with an external resistance). The d-axis synchronous reactance $x_{d}$, the $\mathrm{d}$-axis subtransient reactance $x_{d}^{\prime \prime}$, and the $\mathrm{d}$-axis transient reactance with open field winding $x_{d}^{\prime \prime \prime}$ are obtained from $X_{d s}(j s)$ and $X_{d o}(j s)$. The d-axis transient reactance $x_{d}^{\prime}$ cannot be measured by the DC decay testing method because the damper winding cannot be opened. So $x_{d}^{\prime}$ uses the extrapolated point from $X_{d s}(j s)$ for its initial value.

Secondly $x_{\ell}^{\prime}$ is determined from $x_{d}, x_{d}^{\prime}, x_{d}^{\prime \prime}$ and $x_{d}^{\prime \prime \prime}$ by letting $x_{23}^{\prime}$ be zero by equivalent transformation. The d-axis damper winding impedance $\left(r_{k d}^{\prime}, x_{k d}^{\prime}\right)$ is determined from $X_{d o}(j s)$. The field winding impedance $\left(R_{f 1}^{\prime}\left(=r_{f}^{\prime}\right), x_{f}^{\prime}\right)$ is determined from $X_{d s}(j s)$. The field winding impedance with an external resistance $\left(R_{f K}^{\prime}, x_{f K}^{\prime}\right)$ is determined from $X_{d k}(j s)$.

Finally, $x_{d}^{\prime}$ is determined. $x_{d}^{\prime}$ is a physically-correct value when the field winding constants converge to $x_{f}^{\prime}=x_{f K}^{\prime}$ and $R_{f K}^{\prime} / R_{f 1}^{\prime}=K$ with $x_{d}^{\prime}$. Under this condition, the $\mathrm{d}$-axis equivalent circuit constants taking into account the mutual leakage reactance are determined.

The proposed method was implemented on a 10kVA-200 V319A-4P-50Hz salient-pole machine. Figure 2 shows the obtained operational impedances. Figure 3 shows $r_{k d}$ for $x_{d}^{\prime}$. Table 1 shows the circuit constants for the converged $x_{d}^{\prime}$. Figure 4 shows the measured and calculated field currents for the sudden three-phase shortcircuit test. In Fig. 4, the calculated value agrees with the measured value, demonstrating the validity of the proposed method.

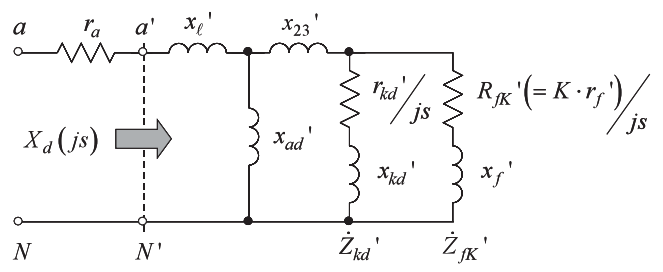

Fig. 1. D-axis equivalent circuit considering $x_{23}$

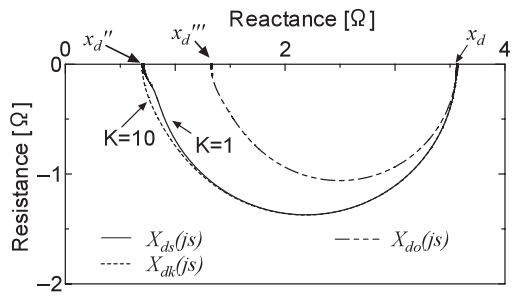

Fig. 2. D-axis operational impedances

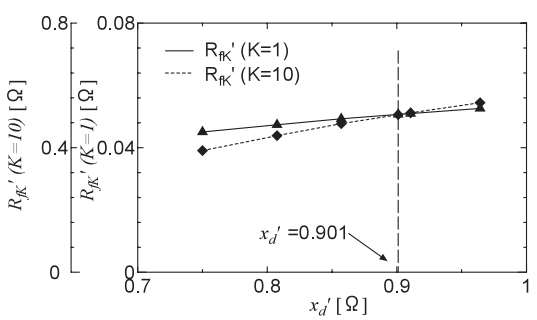

Fig. 3. $x_{d}^{\prime}-R_{f K}^{\prime}$ characteristics

Table 1. D-axis equivalent circuit constants $[\Omega]$

\begin{tabular}{|c|c|c|c|c|c|c|c|}
\hline$r_{a}$ & $x_{i}^{\prime}$ & $x_{23^{\prime}}$ & $x_{a d^{\prime}}$ & $r_{k d^{\prime}}$ & $x_{k d^{\prime}}$ & $r_{f^{\prime}}$ & $x_{f^{\prime}}$ \\
\hline 0.160 & 0.221 & 0 & 3.34 & 0.595 & 1.72 & 0.051 & 0.860 \\
\hline
\end{tabular}

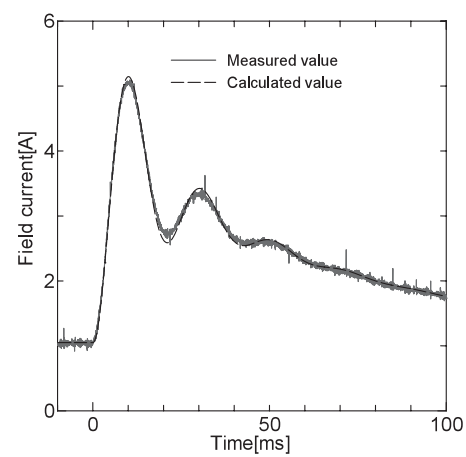

Fig. 4. Measured and calculated field currents 


\title{
相互漏れリアクタンスを考慮した 制動巻線付き同期機の等価回路定数算出法
}

\author{
正 員 狩野 隆志* 正員 中山 大樹** \\ 上級会員 荒 隆裕** 正 員 松村 年郎*
}

\section{A Calculation Method of Equivalent Circuit Constants with Mutual Leakage Reactance on Synchronous Machine with Damper Winding}

Takashi Kano*, Member, Hiroki Nakayama**, Member, Takahiro Ara**, Senior Member, Toshiro Matsumura*, Member

The mutual leakage reactance between the d-axis damper and field windings is ignored in the conventional d-axis equivalent circuit. It has been pointed out that the calculated value of the field transient current differs considerably from the measured value when this reactance is not taken into account. A method to determine this reactance has been reported previously, but this method has problems concerning the measurement precision. The authors have previously presented a calculation method of equivalent circuits, adapting a DC decay testing method, using two synchronous machines of the same specifications (one with damper winding, the other without). Yet, this method is not practical because of the use of two machines.

This paper presents a calculation method of equivalent circuit constants taking into account the mutual leakage reactance to accurately represent the field transient current using a single machine. The proposed method determines equivalent circuit constants by calculating the physically-correct d-axis transient reactance from the operational impedances when the field winding is shorted and when the field winding is shorted with an external resistance. The validity of the proposed method is demonstrated by comparing the measured values with the calculated values of field and armature currents at sudden three-phase short-circuit.

キーワード：同期機，界磁電流，相互漏れリアクタンス，直軸過渡リアクタンス，直流試験法，等価回路

Keywords: synchronous machine, field current, mutual leakage reactance, d-axis transient reactance, DC decay testing method, equivalent circuit

\section{1. はじめに}

同期機の等価回路定数は，三相突発短絡時，線間短絡時， 非同期投入時などにおける電機子電流, 界磁電流を算出する ために必要となる。このためには，等価回路定数をいかに 精度良く算出するかが重要な要素となる。一般に, 直軸お よび横軸の等価回路定数は, 電気学会電気規格調査会標準規 格 JEC-2130 や国際規格 IEC60034-4 など規定されてい る試験から測定できる諸定数 $\left(x_{d}, x_{d}^{\prime}, x_{d}^{\prime \prime}, T_{d}^{\prime}, T_{d}^{\prime \prime}, x_{q}, x_{q}^{\prime \prime}, T_{q}^{\prime \prime}\right)$ を用いて算出している(1) (3)。これらの諸定数から算出する

\footnotetext{
* 名古屋大学

于 464-8603 名古屋市千種区不老町

Nagoya University

Furo-cho, Chikusa-ku, Nagoya 464-8603

**職業能力開発総合大学校

于 229-1196 相模原市橋本台 4-1-1

Polytechnic University

4-1-1, Hashimotodai, Sagamihara 229-1196
}

直軸等価回路定数には界磁巻線と制動巻線との間の相互漏 れリアクタンスを含んでいない。このため, 突発短絡時に おける界磁電流に誤差を生じることが指摘されている ${ }^{(4)}$ 。 の相互漏れリアクタンスを算出する方法として, 三相突発短 絡時の界磁電流の包絡值から直軸制動巻線の時定数を求め る方法が提案されている ${ }^{(5)}$ 。この方法は, 電機子時定数の小 さい小容量機においては振動分が少ないので, 中·大容量機 に比べて包絡值を得ることが困難であるという問題がある。

以上の背景のもと, 著者らは小容量機においても界磁過 渡特性を精度良く表すことができる等価回路定数の算出法 を検討している。これまで，基礎的検討として制動巻線の 有無のみ異なる同一仕様の 2 台の同期機に直流試験法 ${ }^{(6)}$ を 適用し, 相互漏れリアクタンスを考慮した等価回路定数を 算出する方法を述べた (7)。また, 従来の界磁過渡特性の検 討 ${ }^{8)}$ では, 界磁巻線を開放した時の直軸過渡リアクタンス を定めていないことに起因して界磁電流の計算值が変化す ることを明らかにした ${ }^{(7)}$ 。しかし, 本算出法は, 供試機と 
は別に制動巻線なしの回転子を製作しなければならず，実 用的ではない。

そこで本論文は, 1 台の同期機から相互漏れリアクタン スの効果を考慮した等価回路定数を算出する方法について 述べている ${ }^{(9)}$ 。この方法は，等価変換 ${ }^{(10)}$ を施すことで相互 漏れリアクタンスを等価的に零とした等価回路 ${ }^{(11)}$ に対し て, 直流試験法によって得られる界磁巻線短絡時および界 磁巻線外部抵抗短絡時の直軸演算子インピーダンスから直 軸過渡リアクタンスを算出することにより，その等価回路 定数を決定するものである。よって, 得られる等価回路定 数值は，等価変換された同期機等価回路に対する值である ため，スロット寸法等から定まる等価回路定数值とは異な る (12)。しかしながら, 従来から広く用いられているシンプ ルな（相互漏狆リアクタンス要素を含まない）等価回路モ デル (8)(13) を用いて，相互漏れリアクタンスの効果を精度良 く加味した界磁特性を算出できる特徵がある。

本方法の妥当性については，三相突発短絡時における界 磁電流の計算值および実測值との比較検討により明らかに している。

\section{2. 直軸等価回路定数の算出法}

$\langle\mathbf{2} \cdot \mathbf{1}\rangle$ 等価回路と演算子インピーダンスの関係 図 1 は，直軸および横軸等価回路である。ここで， $r_{a}$ : 電機子 巻線抵抗, $x_{\ell}$ : 電機子漏れリアクタンス, $x_{a d}, x_{a q}$ : 直軸抒 よび横軸電機子反作用リアクタンス, $x_{k d}, x_{k q}$ : 直軸拉よび 横軸制動巻線漏れリアクタンス, $r_{k d}, r_{k q}$ : 直軸および横軸 制動巻線抵抗, $x_{f}$ : 界磁巻線漏れリアクタンス, $r_{f}$ : 界磁 巻線抵抗, $x_{23}$ : 界磁巻線と制動巻線間の相互漏れリアク夕 ンス, $s:$ すべり, $X_{d}(j s), X_{q}(j s)$ : 直軸执よび横軸演算子 インピーダンスである。 $X_{d}(j s)$ および $X_{q}(j s)$ は, 小容量の 直流電源を用いた静止試験法として著者らが既に提案する 直流試験法から求めることができる(日)。

図 2 は, 直軸演算子インピーダンス $X_{d}(j s)$ の軌跡例であ る。図中の $X_{d s}(j s)$ は界磁巻線抵抗短絡時 $(K=1), X_{d o}(j s)$ は界磁巻線開放時における図 1(a) の端子 $\mathrm{a}^{\prime}-\mathrm{N}^{\prime}$ から見た演 算子インピーダンスである。

次に, 図 1(a)の直軸等価回路と図 2 の $x_{d}, x_{d}^{\prime \prime}, x_{d}^{\prime \prime \prime}$ お よび $x_{d}^{\prime}$ との関係について述べる。 $x_{d}$ は, 図 1(a)において $s=0$ としたときの端子 $\mathrm{a}^{\prime}-\mathrm{N}^{\prime}$ 間から見た合成リアクタンス であり，直軸同期リアクタンスと呼ばれる。 $x_{d}^{\prime \prime}$ は，図 1(a) に执いて $s=\infty$ としたときの端子 $\mathrm{a}^{\prime}-\mathrm{N}^{\prime}$ 間から見た合成リ アクタンスであり, 直軸初期過渡リアクタンスと呼ばれる。 $x_{d}^{\prime \prime \prime}$ は，図1(a)において界磁巻線が開放時に $s=\infty$ とした ときの端子 $\mathrm{a}^{\prime}-\mathrm{N}^{\prime}$ 間から見た合成リアクタンスであり, 界 磁巻線開放時の直軸過渡リアクタンスと仮称する。 $x_{d}^{\prime}$ は, 図 1(a)に拈いて制動巻線が開放時に $s=\infty$ としたときの 端子 $\mathrm{a}^{\prime}-\mathrm{N}^{\prime}$ 間から見た合成リアクタンスであり, 直軸過渡 リアクタンスと呼ばれる。

横軸演算子インピーダンス $X_{q}(j s)$ についても直軸の場合 と同様に, 直流試験法により算出することができる。 $X_{q}(j s)$

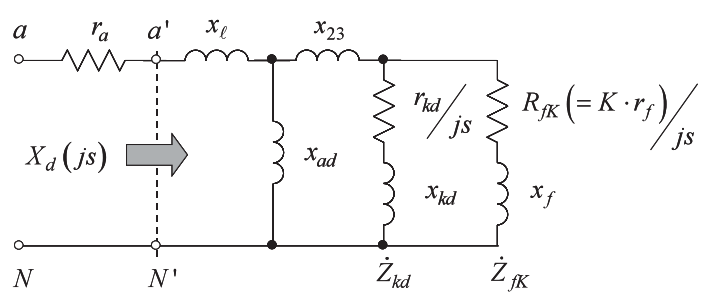

(a) D-axis equivalent circuit

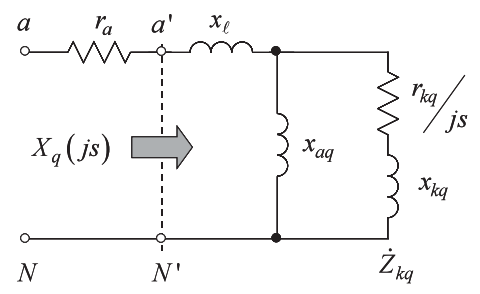

(b) Q-axis equivalent circuit

図 1 相互漏れリアクタンスを考慮した等価回路

Fig. 1. Equivalent circuits with mutual leakage reactance $x_{23}$.

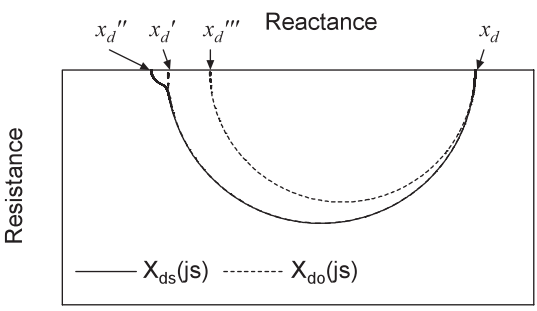

図 2 直軸演算子インピーダンス軌跡例

Fig. 2. Example of d-axis operational impedances.

から $s=0$ および $s=\infty$ の横軸同期リアクタンス $x_{q}$ および 横軸初期過渡リアクタンス $x_{q}^{\prime \prime}$ を求めることができる。 $x_{q}$ は, 図 1(b) において $s=0$ としたときの端子 $\mathrm{a}^{\prime}-\mathrm{N}^{\prime}$ 間から 見た合成リアクタンスである。 $x_{q}^{\prime \prime}$ は, 同様に $s=\infty$ にお ける端子 $\mathrm{a}^{\prime}-\mathrm{N}^{\prime}$ 間から見た合成リアクタンスに対応する。

$\langle\mathbf{2} \cdot \mathbf{2}\rangle$ 直軸等価回路と過渡リアクタンスの関係 図 1 (a)の直軸等価回路に扔いて, これら端子 $\mathrm{a}^{\prime}-\mathrm{N}^{\prime}$ 間から見た リアクタンス $\left(x_{d}, x_{d}^{\prime \prime}, x_{d}^{\prime \prime \prime}, x_{d}^{\prime}\right)$ と等価回路定数との関係を示 すと (1) (4) 式となる。

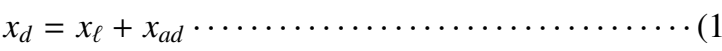

$$
\begin{aligned}
& x_{d}^{\prime \prime}=x_{\ell}+\frac{1}{\frac{1}{x_{a d}}+\frac{1}{x_{23}+\frac{1}{\frac{1}{x_{f}}+\frac{1}{x_{k d}}}}} \\
& x_{d}^{\prime \prime \prime}=x_{\ell}+\frac{1}{\frac{1}{x_{a d}}+\frac{1}{x_{23}+x_{k d}}} \\
& x_{d}^{\prime}=x_{\ell}+\frac{1}{\frac{1}{x_{a d}}+\frac{1}{x_{23}+x_{f}}} \text {. }
\end{aligned}
$$

(1) （4) 式の右辺の定数 $\left(x_{\ell}, x_{a d}, x_{23}, x_{k d}, x_{f}\right)$ は, すべて 未知数である。また, 左辺の定数 $\left(x_{d}, x_{d}^{\prime \prime}, x_{d}^{\prime \prime \prime}\right)$ は, 直流試験 


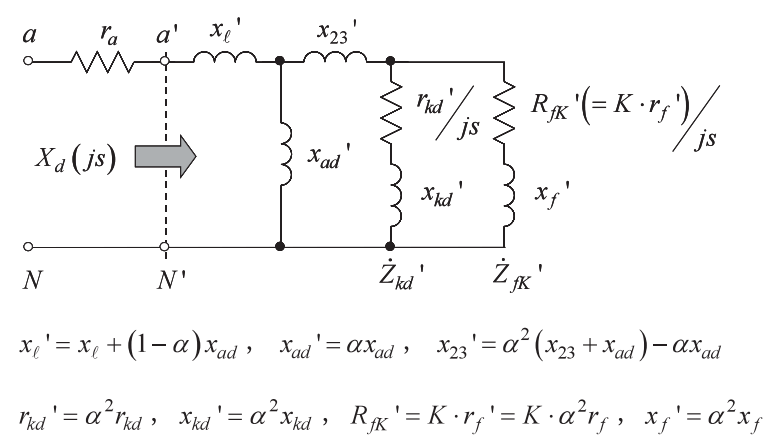

図 3 等価変換した直軸等価回路

Fig. 3. Equivalently-transformed d-axis equivalent circuit.

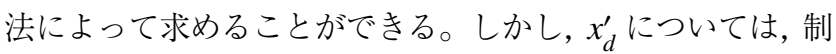
動巻線を開放した状態で直流試験法を実施することができ ないので，この試験から求められない。したがって，(1) (4) 式の未知数は, $6 つ\left(x_{\ell}, x_{a d}, x_{23}, x_{k d}, x_{f}, x_{d}^{\prime}\right)$ となるため にこのままでは連立方程式の解を得ることができない。

$\langle\mathbf{2} \cdot \mathbf{3}\rangle$ 直軸等価回路の等価变換 図 3 は, 文献 (10) を参考に図 1(a) を等価変換した直軸等価回路である。 $\alpha$ は, 変換係数である。 $\alpha$ を変化すれば等価回路定数も变化する。 よって, 相互漏れリアクタンス $x_{23}^{\prime}$ が零でありながら, 図 1 と等価な回路モデルも存在する(11)。しかしながら，このと きの同期機諸定数の值は $\alpha$ には依存しない。例えば, (5) 式 は, 三相突発短絡時における界磁電流 $i_{f}$ の計算式として広 く知られている(8)。

$i_{f}=i_{f 0}+\frac{x_{d}-x_{d}^{\prime}}{x_{d}^{\prime}} i_{f 0}\left\{\varepsilon^{-t / T_{d}^{\prime}}-\left(1-\frac{T_{k d}}{T_{d}^{\prime \prime}}\right) \varepsilon^{-t / T_{d}^{\prime \prime}}-\frac{T_{k d}}{T_{d}^{\prime \prime}} \varepsilon^{-t / T_{a}} \cos \omega_{0} t\right\}$

ここで, $i_{f 0}$ : 短絡前界磁電流值, $T_{d}^{\prime}$ : 直軸短絡過渡時定 数, $T_{d}^{\prime \prime}$ : 直軸短絡初期過渡時定数, $T_{a}$ : 電機子時定数, $T_{k d}$ : 直軸制動巻線の時定数， $\omega_{0}$ : 同期速度である。

(5) 式の右辺に扔いて, $T_{k d}$ を図 3 の等価回路定数から求 めると,

$$
T_{k d}=\frac{x_{k d}^{\prime}}{\omega_{0} r_{k d}^{\prime}}=\frac{\alpha^{2} x_{k d}}{\omega_{0} \alpha^{2} r_{k d}}=\frac{x_{k d}}{\omega_{0} r_{k d}} .
$$

となり, $\alpha$ に依存しないことがわかる。同様に $\left(x_{d}, x_{d}^{\prime}, T_{d}^{\prime}, T_{d}^{\prime \prime}\right.$, $\left.T_{a}\right)$ についても図 3 から求めることができ, $\alpha$ に依存しない。

以下, 本論文では, 図 3 において $x_{23}^{\prime}$ を零とする後述の 図 4 に示す反復計算により, 相互漏れリアクタンス $x_{23}^{\prime}=0$, かつ, 相互漏れリアクタンスの突発短絡時界磁電流への影 響を考慮した等価回路定数を算出する。

$\langle\mathbf{2} \cdot \mathbf{4}\rangle$ 直軸等価回路定数の算出法 (1) (4) 式に打い て, $x_{23}=0$ とすること, 拈よび直流試験法から求められな い $x_{d}^{\prime}$ を仮定することで，その他の未知数を解くことができ る。図 4 は, 提案する直軸等価回路定数の算出法である。 以下，その方法を述べる。

始めに, 直流試験法から界磁巻線開放時, 界磁巻線短絡 時，および界磁巻線外部抵抗短絡時の直軸演算子インピー

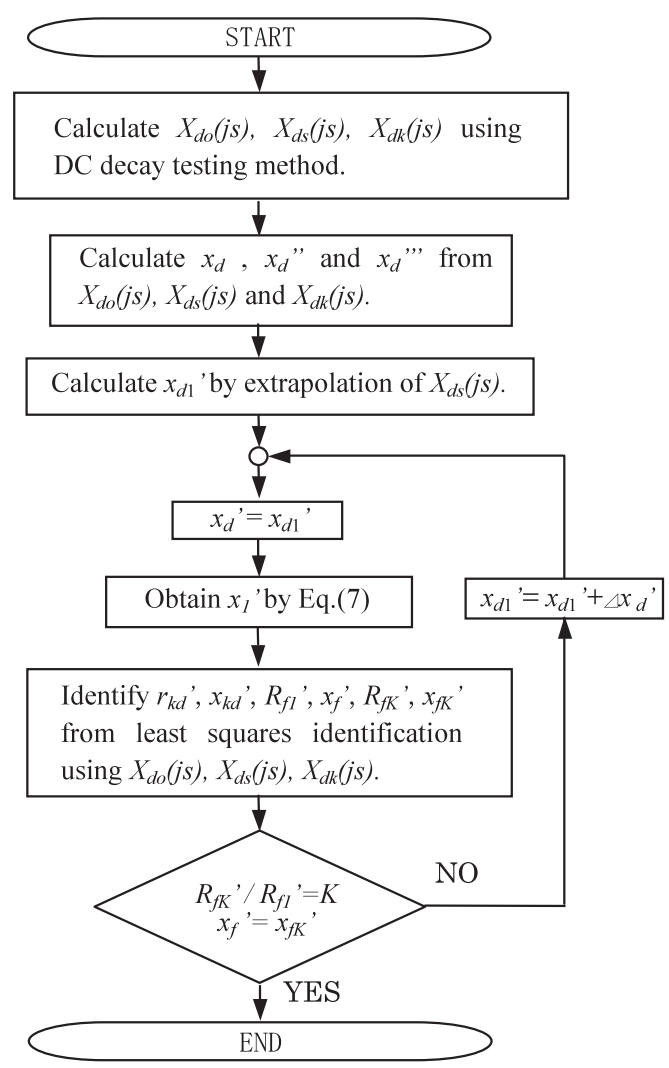

図 4 直軸等価回路定数の算出法

Fig. 4. Calculation method of d-axis equivalent circuit constants.

ダンス $X_{d o}(j s), X_{d s}(j s)$, および $X_{d k}(j s)$ を算出する。これ ら直軸演算子インピーダンスから, 定数 $\left(x_{d}, x_{d}^{\prime \prime}, x_{d}^{\prime \prime \prime}\right)$ を求 める。 $x_{d}^{\prime}$ は, 直流試験法から求めることができないので,

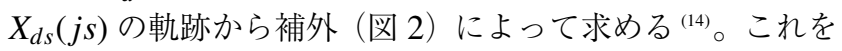
初期值 $x_{d 1}^{\prime}$ として, (4) 式の $x_{d}^{\prime}$ に代入する。これより，(1) (4) 式の左辺定数 $\left(x_{d}, x_{d}^{\prime \prime}, x_{d}^{\prime \prime \prime}, x_{d}^{\prime}\right)$ が定まる。

次に, 直軸等価回路定数を求める。 $x_{23}^{\prime}=0$ とする電機子 漏れリアクタンス $x_{\ell}^{\prime}$ を(1)〜(4) 式より求めると,

$x_{\ell}^{\prime}=\frac{\left(x_{d} x_{d}^{\prime \prime}-x_{d}^{\prime} x_{d}^{\prime \prime \prime}\right)-\sqrt{\left(x_{d}-x_{d}^{\prime \prime \prime}\right)\left(x_{d}-x_{d}^{\prime}\right)\left(x_{d}^{\prime}-x_{d}^{\prime \prime}\right)\left(x_{d}^{\prime \prime \prime}-x_{d}^{\prime \prime}\right)}}{\left(x_{d}-x_{d}^{\prime \prime \prime}\right)-\left(x_{d}^{\prime}-x_{d}^{\prime \prime}\right)}$

となる。

直軸電機子反作用リアクタンス $x_{a d}^{\prime}$ は, (1) 式により $x_{d}$ から $x_{\ell}^{\prime}$ を差し引くことで求まる。

直軸制動巻線インピーダンス $\left(r_{k d}^{\prime}, x_{k d}^{\prime}\right)$ は, 前述より求ま る定数 $\left(x_{\ell}^{\prime}, x_{a d}^{\prime}\right)$ を用いて界磁巻線開放時の直軸演算子イン ピーダンス $X_{d o}(j s)$ から最小二乗法によって同定する。こ こでは同定精度を高めるために直軸制動巻線回路を 2 回路 とおいて同定し，同定した值を合成することにより $r_{k d}^{\prime}, x_{k d}^{\prime}$ を同定している。同定方法については文献 (6), (14) に詳述 している。

界磁巻線短絡時のインピーダンス $\left(R_{f 1}^{\prime}\left(=r_{f}^{\prime}\right), x_{f}^{\prime}\right)$ は, 前 述より求まる定数 $\left(x_{\ell}^{\prime}, x_{a d}^{\prime}, r_{k d}^{\prime}, x_{k d}^{\prime}\right)$ を用いて界磁巻線短絡時 
の直軸演算子インピーダンス $X_{d s}(j s)$ から最小二乗法によっ て同定する。

以上の方法によって求めた直軸等価回路定数は, $x_{d}^{\prime}$ を仮 定した場合であるので, 界磁巻線外部抵抗短絡時のインピー ダンスを用いてこれら定数の良否判定を行う。界磁巻線外 部抵抗短絡時のインピーダンス $\left(R_{f K}^{\prime}\left(=K \cdot r_{f}^{\prime}\right), x_{f K}^{\prime}\right)$ は, 前述 上り求まる定数 $\left(x_{\ell}^{\prime}, x_{a d}^{\prime}, r_{k d}^{\prime}, x_{k d}^{\prime}\right)$ を用いて界磁巻線外部抵抗 短絡時の直軸演算子インピーダンス $X_{d k}(j s)$ から最小二乗法 によって同定する。同定した界磁巻線短絡時掞よび外部抵 抗短絡時の界磁巻線インピーダンスにおいて, $R_{f K}^{\prime} / R_{f 1}^{\prime}=K$ および $x_{f}^{\prime}=x_{f K}^{\prime}$ の関倸を判別する。この関倸が成り立た ない場合は，初期值 $x_{d 1}^{\prime}$ を $\Delta x_{d 1}^{\prime}$ だけ変化させ，成り立つま で同定を繰り返す。なお, 電機子巻線抵抗 $r_{a}$ については, 直流電圧降下法加算出する。

$x_{d}^{\prime}$ は, 図 3 の直軸等価回路より,

$$
\begin{aligned}
x_{d}^{\prime} & =x_{\ell}+(1-\alpha) x_{a d}+\frac{1}{\frac{1}{\alpha x_{a d}}+\frac{1}{\alpha^{2}\left(x_{23}+x_{a d}\right)-\alpha x_{a d}+\alpha^{2} x_{f}}} \\
& =x_{\ell}+\frac{x_{a d}\left(x_{23}+x_{f}\right)}{x_{a d}+x_{23}+x_{f}} \ldots \ldots \ldots \ldots \ldots \ldots \ldots \ldots \ldots \text { (8) }
\end{aligned}
$$

となり， $\alpha$ とは無関係となっている。すなわち， $x_{d}^{\prime}$ は仮定 した $\alpha$ によらず一つの值に定まる。

横軸等価回路定数については, 直軸等価回路と同様に求め る。まず, 直流試験法から横軸演算子インピーダンス $X_{q}(j s)$ を算出し, $s=0$ における横軸同期リアクタンス $x_{q}$ を求め る。横軸電機子反作用リアクタンス $x_{a q}^{\prime}$ は, (1) 式と同様に $x_{q}$ から直軸等価回路で算出した $x_{\ell}^{\prime}$ の值を差し引くことで 求まる。横軸制動巻線インピーダンス $\left(x_{k q}^{\prime}, r_{k q}^{\prime}\right)$ は, 算出し た定数 $\left(x_{\ell}^{\prime}, x_{a q}^{\prime}\right)$ を用いて横軸演算子インピーダンス $X_{q}(j s)$ から最小二乗法によって同定する。な技，直軸の場合と同 様に横軸制動巻線回路は, 並列 2 回路として同定した後に 合成する。以上の方法により直軸㧍よび横軸等価回路定数 が算出される。

\section{3. 実施例と考察}

〈3・1〉 直軸過渡リアクタンスおよび等価回路定数の算出 結果 供試機は, 積層磁極突極形同期機 $(10 \mathrm{~kW}, 200 \mathrm{~V}$, $31.9 \mathrm{~A}, 50 \mathrm{~Hz}$ ) を用いた。表 1 は，供試機の仕様である。 演算子インピーダンスは，文献(6)に示すように直流試験 法を実施した。図 5 は, 回転子を直軸の位置に固定したと きの界磁巻線開放時, 界磁巻線短絡時 $(K=1)$, および 外部抵抗短絡時 $(K=10)$ における直軸演算子インピー ダンス $X_{d o}(j s), X_{d s}(j s), X_{d k}(j s)$ の軌跡である。これより, $x_{d}=3.56[\Omega], x_{d}^{\prime \prime}=0.706[\Omega], x_{d}^{\prime \prime \prime}=1.32[\Omega]$ であった。

図 6 は, 界磁巻線を開放した状態で, 回転子を横軸の位置 に固定したときの横軸演算子インピーダンス $X_{q o}(j s)$ であ る。これより， $x_{q}$ および $x_{q}^{\prime \prime}$ は，それぞれ $2.20[\Omega], 0.766[\Omega]$ であった。

これら $x_{d}, x_{d}^{\prime \prime}, x_{d}^{\prime \prime \prime}, x_{q}, x_{q}^{\prime \prime}, X_{d o}(j s), X_{d s}(j s), X_{d k}(j s)$, および $X_{q o}(j s)$ を用いて 2 章の方法により，直軸および横軸
表 1 供試機の仕様

Table 1. Specifications of the tested machine.

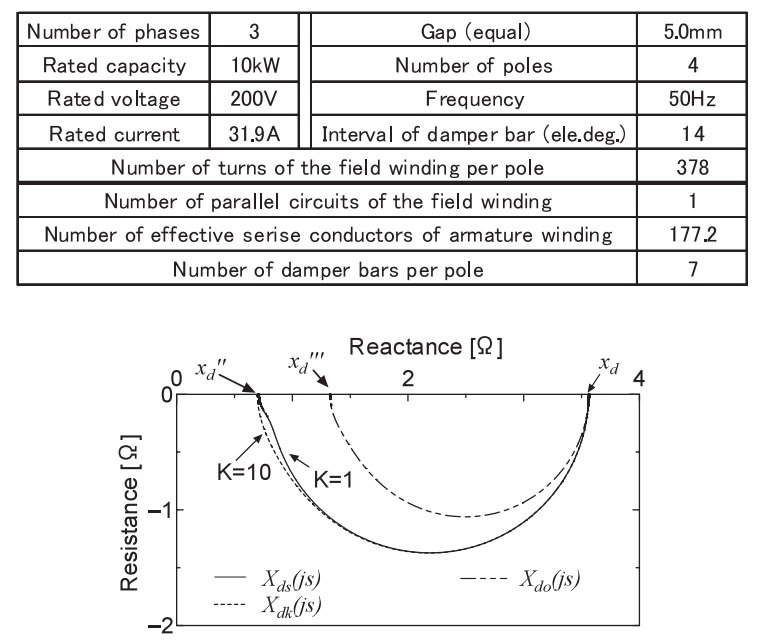

困 5 直軸演算子インピーダンス

Fig. 5. D-axis operational impedances.

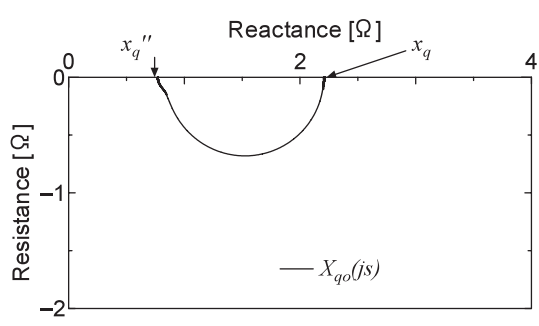

図 6 横軸演算子インピーダンス

Fig.6. Q-axis operational impedance.

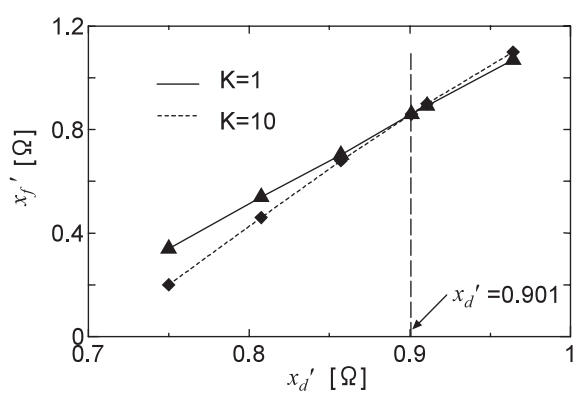

図 $7 x_{d}^{\prime}$ に対する $x_{f}^{\prime}$ の值

Fig. 7. $x_{d}^{\prime}-x_{f}^{\prime}$ characteristics.

の等価回路定数を算出した。 $x_{d}^{\prime}$ の初期值 $x_{d 1}^{\prime}$ は, $X_{d s}(j s)$ の 軌跡を用いて補外によって求めた結果 $0.790[\Omega]$ を用いた。

図 7 および図 8 は， $x_{d}^{\prime}$ を変化させたときの界磁巻線抵 抗 $\left(R_{f 1}^{\prime}, R_{f K}^{\prime}\right)$ ，およびリアクタンス $\left(x_{f}^{\prime}, x_{f K}^{\prime}\right)$ の関係である。 図 7 抢よび図 8 の実線と点線の交わる点が $R_{f K}^{\prime} / R_{f 1}^{\prime}=10$ および $x_{f}^{\prime}=x_{f K}^{\prime}$ の関係を満たす $x_{d}^{\prime}$ であり, $x_{d}^{\prime}=0.901[\Omega]$ となった。このとき $x_{\ell}^{\prime} は, 0.221[\Omega]$ となり, 等価回路定 数の算出結果は表 2 のと㧍りである。

〈3·2〉 直軸過渡リアクタンスの比較 表 3 は, 各種 算出法から求めた直軸過渡リアクタンス $x_{d}^{\prime}$ である。表 3 の (1) は，本方法より算出した值である。表 3 の (2) は, 


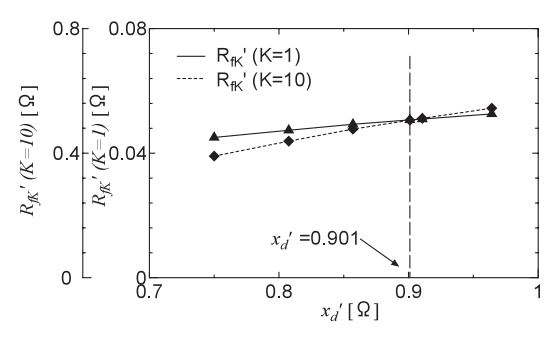

図 $8 x_{d}^{\prime}$ に対する $R_{f K}^{\prime}$ の值

Fig. 8. $x_{d}^{\prime}-R_{f K}^{\prime}$ characteristics.

表 2 等価回路定数 [ $\Omega$ ]

Table 2. Equivalent circuit constants $[\Omega]$.

\begin{tabular}{|c|c|c|c|}
\hline \multicolumn{2}{|c|}{ D-axis } & \multicolumn{2}{c|}{ Q-axis } \\
\hline$r_{a}$ & 0.160 & $r_{a}$ & 0.160 \\
\hline$x_{\prime}{ }^{\prime}$ & 0.221 & $x_{\prime}{ }^{\prime}$ & 0.221 \\
\hline$x_{23}{ }^{\prime}$ & 0 & & \\
\hline$x_{a d}{ }^{\prime}$ & 3.34 & $x_{a q}{ }^{\prime}$ & 1.98 \\
\hline$r_{k d^{\prime}}{ }^{\prime}$ & 0.595 & $r_{k q}{ }^{\prime}$ & 0.295 \\
\hline$x_{k d^{\prime}}{ }^{\prime}$ & 1.72 & $x_{k q}{ }^{\prime}$ & 0.868 \\
\hline$r_{f}{ }^{\prime}$ & 0.051 & & \\
\hline$x_{f}{ }^{\prime}$ & 0.860 & & \\
\hline
\end{tabular}

表 3 直軸過渡リアクタンス $x_{d}^{\prime}$

Table 3. D-axis transient reactance $x_{d}^{\prime}$.

\begin{tabular}{|c|l|c|}
\hline No. & determination method of $x_{d}{ }^{\prime}$ & $x_{d}{ }^{\prime}$ \\
\hline$(1)$ & method of $\langle 2-4\rangle$ & 0.901 \\
\hline$(2)$ & sudden three-phase short-circuit test & 0.902 \\
\hline$(3)$ & $\begin{array}{l}\text { DC decay testing method } \\
\text { (machine without damper) }\end{array}$ & 0.897 \\
\hline
\end{tabular}

JEC-2130に記載される三相突発短絡試験より算出した值 である。表 3 の (3) は, 制動巻線を配置していないことの み異なる同一仕様の供試機を用いて直流試験法を実施し, 界磁巻線短絡時の直軸演算子インピーダンスから算出した 值である。

表 3 の (3) における $x_{d}^{\prime}$ は, 制動巻線の影響を受けずに算 出できることから，この值を基準に本方法の值を比較する と $0.45 \%(=((0.901-0.897) / 0.897) \times 100)$ の差となった。 このことから, 本方法による $x_{d}^{\prime}$ は精度よく算出されたこと が確認できる。

$\langle 3 \cdot 3\rangle$ 三相突発短絡電流の実測值と計算值の比較検討

三相突発短絡試験は，図 9 に示すように原動機であるべ クトル制御誘導電動機（IM）と被試験機である同期発電機 （SG）を直結し，JEC-2130の手順により行った。三相突発 短絡のためのスイッチとして水銀リレーを使用し, 短絡時の 界磁電流および電機子電流をアナライジングレコーダ (サン プリング間隔 $20[\mu \mathrm{s}]$ ）を用いて測定した。短絡前の無負荷 電圧は, 44.9 [V] (線間電圧の実効值), 界磁電流 1.05 [A], 短絡前後の回転速度 $1495\left[\mathrm{~min}^{-1}\right]$ であった。また，シミュ レーションも実施した。そこでは，電圧・磁束鎖交方程式 をシミュレーション用ソフト ACSL ${ }^{(15)}$ を用いて解くことに

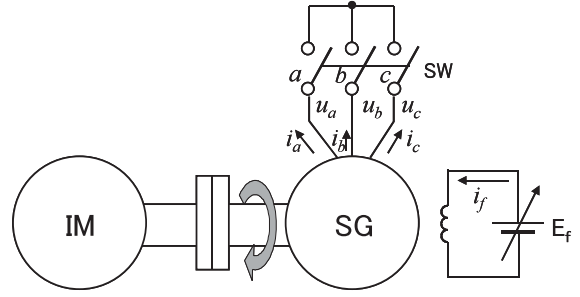

図 9 三相突発短絡回路

Fig. 9. Sudden three-phase short-circuit.

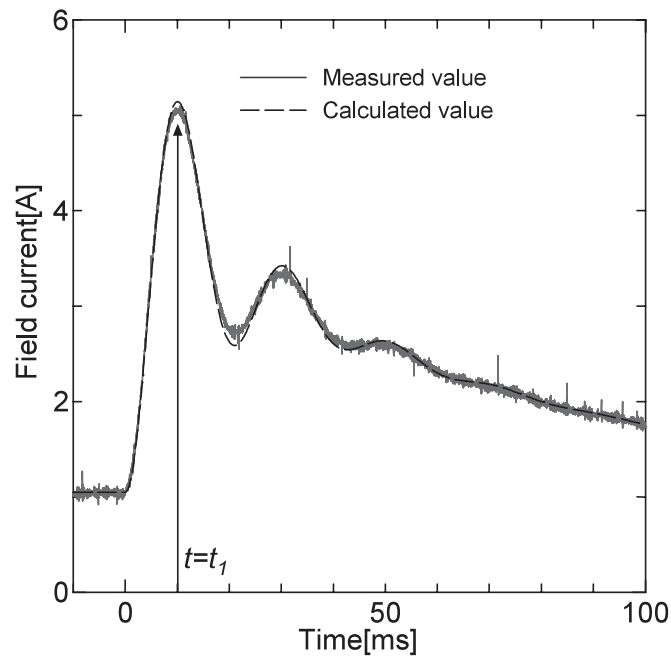

図 10 界磁電流の実測值と計算值

Fig. 10. Measured and calculated field currents.

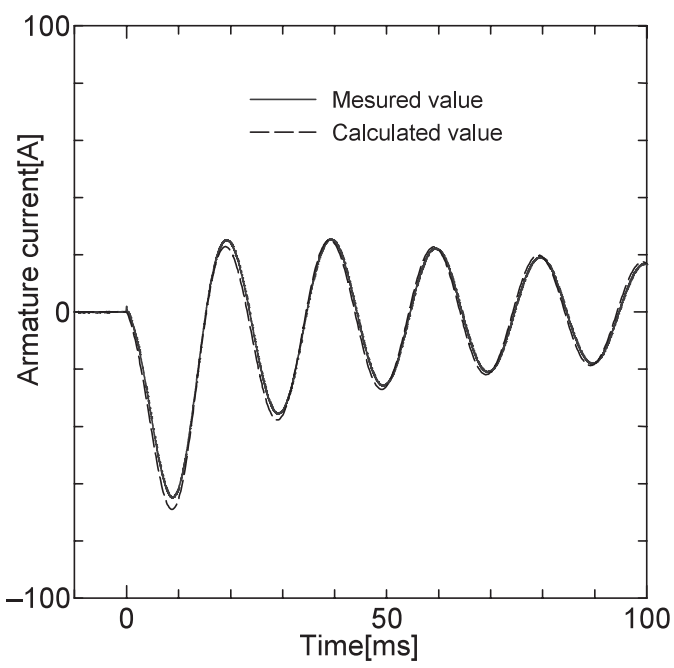

困 11 電機子電流の実測值と計算值

Fig. 11. Measured and calculated armature currents.

より，界磁電流および電機子電流の計算を行った。

本算定法で等価回路定数を算定すれば， $x_{23}=0$ としたシ ンプルな等価回路モデルを用いても, 従来法で相互漏れリア クタンス $x_{23}$ を考慮しないために生じていた誤差を低減でき る。例えば, 図 10 は, 三相突発短絡時の界磁電流である。実 線が実測值, 鎖線が表 2 の等価回路定数を用いた計算值であ る。界磁過渡電流の第 1 番目のピーク（図 10 の時刻 $t=t_{1}$ の 
ポイント)における計算値は $5.16 \mathrm{~A}$ であり, 実測值 $(5.05 \mathrm{~A})$ を基準としたときの差は $2.2 \%$ (= ((5.16-5.05)/5.05)×100) である。よって, 計算值と実測值は良く一致していること から，本方法による相互漏れリアクタンスの効果を考慮し た等価回路定数算出法の妥当性が確認できる。

図 11 は，三相突発短絡時の電機子電流である。実線が 実測值, 鎖線が表 2 の等価回路定数を用いた計算值である。 計算值と実測值を比較するとよく一致していることが確認 できる。

\section{4. まとめ}

界磁巻線掞よび制動巻線間の相互漏れリアクタンスを考 慮した直軸等価回路定数および横軸等価回路定数の算出法 について述べた。まとめると以下のと㧍りである。

（1）直流試験法から求まる界磁巻線短絡時㧍よび外部 抵抗短絡時の直軸演算子インピーダンスを用いて, 相互漏 れリアクタンスを考慮した等価回路定数を算出する方法を 示した。

（2）本論文の算出結果は，相互漏れリアクタンスを零 とした等価回路モデルの形をとるが，相互漏れリアクタン ス $x_{23}$ を考慮しないために生じていた誤差が低減できた。

（3）本論文の算出法による等価回路定数を用いた界磁 過渡特性は，三相突発短絡時における界磁電流の計算値と 実測値との比較検討から精度良く計算できることを明らか にした。

最後に，日頃，御提言いただく（株）東芝平松大典様に 感謝の意を表します。

(平成 18 年 10 月 13 日受付, 平成 19 年 2 月 9 日再受付)

\section{文献}

（1）電気学会電気規格調查会：「電気学会電気規格調査会標準規格同期 機 (JEC-2130-2000) 」, 電気書院 (2001)

(2) International Electrotechnical Commission Standard: "Methods for Determining Synchronous Machine Quantities from Test (IEC 60034-4)", International Electrotechnical Commission (IEC) (1985)

(3) R.H. Park: "Two-Reaction Theory of Synchronous Machines Part1", AIEE (1929)

(4) I.M. Canay: "Causes of Discrepancies on Calculation of Rotor Quantities and Exact Equivalent Diagrams of the Synchronous Machine", IEEE Trans, Vol.PASS-88, No.7 (1969)

(5) Y. Takeda and B. Adkins: "Determination of synchronous machine parameters Allowing for unequal mutual inductances", PROC.IEE, Vol.121, No.12, pp.1501-1504 (1974)

(6) T. Ara, T. Akima, and S. Oda: "A Method to Predict Transient Constant for Synchronous Machine", IEEJ Trans. IA, Vol.115, No.6 pp.694-701 (1995-

荒 隆裕 - 秋間紳樹 - 小田荘一: 「同期機の過渡諸定数推定法」, 電学 論 D, 115, 6, pp.694-701 (1995-6)

(7) T. Kano, S. Yamamoto, and T. Ara: "A Calculation Method of Field Current of Synchronous Machines at Sudden Short-circuit", IEEJ Trans. IA, Vol.124, No.3, pp.304-311 (2004-3)

狩野隆志・山本 修·荒 隆裕: 「同期機の突発短絡時に打ける界磁 電流算出法上,電学論 D, 124, No.3, pp. 304-311 (2004-3)

（8）猪狩武尚：電気機械理論, コロナ社 (1977)

(9) H. Nakayama, T. Kano, S. Yamamoto, and T. Ara: "A Calculation Method of Equivalent Circuit Constants with Mutual Leakage Reactance", IEEJ RM05-141, pp.7-11 (2005-10)
中山大樹·狩野隆志・山本 修·荒 隆裕: [同期機の相互漏れリアク タンスを考慮した等価回路定数算出法」, 電学回転機研資 RM-05-141, pp.7-11 (2005-10)

10）山村 昌：交流モー夕の解析と制御, オーム社 (1988)

(11) I.M. Canay: "Determination of model parameters of synchronous machines", IEE Proc., Vol.130, Pt. B, No.2, pp.86-94 (1983-3)

(12) J. Tamura, R. Takahashi, T. Takazawa, Y. Tada, and A. Kurita: "Characteristics of Canay Inductance of Synchronous Machines and Its Effects on Transient Stability", IEEJ Trans. IA, Vol.124, No.7, pp.706-715 (2004-7) 田村淳二・高橋理音・高澤 毅・多田泰之・栗田 篤:「同期機に扔 ける Canny インダクタンスの特性と過渡安定度に対する影響につい て」, 電学論 D, 124, 7, pp.706-715 (2004-7)

(13) C. Concordia: Synchronous Machines, Wiley, New York (1951)

(14) T. Ara, A. Hiraga, and S. Yamamoto: "Determination of Equivalent Circuit Constants of Synchronous Machine from the Extended Dalton-Cameron Method", IEEJ Trans. IA, Vol.121, No.1, pp.66-73 (2001-1) 荒 隆裕·平賀 章・山本 修:「拡張ダルトン一カメロン法による 同期機の等価回路定数算出法」, 電学論 D, 121, 1, pp.66-73 (2001-1)

（15）連続型シミュレーションソフトウェア「ACSL」, MGA Software

狩 野 隆 志 (正員) 1977 年 11 月 30 日生。 2003 年 3 月, 職

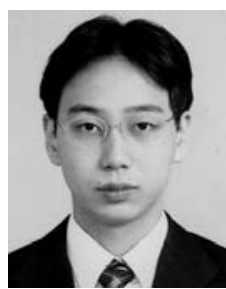
業能力開発総合大学校研究課程工学研究科電気. 情報専攻修了。同年 4 月，雇用・能力開発機構に 入り岡山職業能力開発促進センター（現：岡山セ ンター）勤務。2006 年 4 月, 名古屋大学大学院 工学研究科博士課程後期に社会人入学。2007 年 4 月職業能力開発総合大学校講師, 現在に至る。

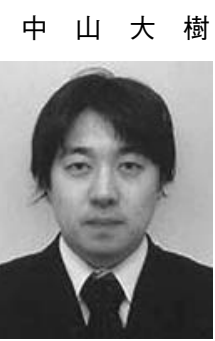

(正員) 1981 年 3 月 13 日生。 2004 年 3 月職業能 力開発総合大学校電気システム工学科卒業。2006 年 3 月, 同校研究課程工学研究科電気・情報専攻 修了。同年 4 月，富士電機システム（株）に入社, 現在に至る。

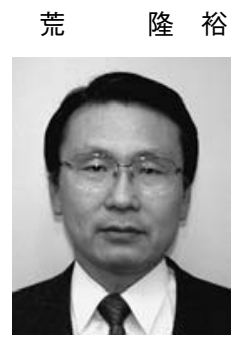

（上級会員） 1977 年 3 月，職業訓練大学校電気 工学科卒業。同年 4 月, 雇用促進事業団（現：雇 用・能力開発機構) に入り浜松総合高等職業訓練 校勤務を経て，1980 年 4 月職業訓練大学校（現： 職業能力開発総合大学校) 助手。講師, 助教授を 経て，2000 年 4 月教授。 2007 年 4 月学生部長, 現在に至る。主として, 電気機械の解析と制御に 関する研究に従事。工学博士。日本産業技術教育 学会会員。IEEE 会員。

松 村 年 郎 (正員) 1951 年 5 月 1 日生。 1979 年 3 月名古

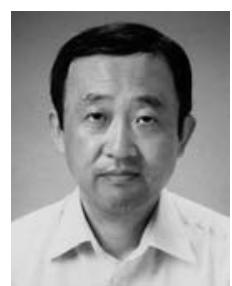
屋大学大学院工学研究科博士課程後期課程満了。 同年 4 月同大学助手。1 987 年 2 月同大学講師。 1989 年 3 月京都大学講師。1992 年 1 月名古屋大 学助教授。1995 年 4 月同大学教授, 現在に至る。 工学博士。主として, 大電流遮断, 電気エネルギー の有効利用に関する研究に従事。IEEE 会員。 